\title{
STUDI KRITIS EXPOSURE DRAFT PSAK SYARIAH
}

\author{
Oleh: \\ Rifqi Muhammad \\ Dosen Fakultas Ekonomi Universitas Islam Indonesia
}

\section{ABSTRAK}

Perkembangan lembaga keuangan syariah di Indonesia telah mendorong munculnya praktik-praktikakuntansi yang beragam. Ikatan Akuntan Indonesia merasa perlu untuk mengatur keeragaman penyusunan dan penyajian laporan keuangan di lembaga-lembaga keuangan syariah tersebut dengan membuat standar. Oleh karena itu Dewan Standar Akuntansi Keuangan (DSAK) segera menyetujui Exposure Draft PSAK Syariah pada November 2006 yang disusun oleh Komite Akuntansi Syariah (KAS).

Tulisan ini bertujuan untukmembahas dan mengevaluasi Exposure Draft (ED) PSAK Syariah. Kesimpulan yang bisa diambil dari kajian ini adalah bahwa ED PSAK Syariah belum sepenuhnya bisa mengakomodasi perkembangan lembaga-lembaga keuangan syariah di Indonesia.

Keywords:pemyataan standar akuntansi keuangan, syariah, exposure draft

Perkembangan praktik lembaga keuangan syariah baik dalam bentuk lembaga keuangan bank maupun non bank telah memotivasi kalangan praktisi, akademisi, serta penyusun standar akuntansi keuangan untuk menyusun sebuah standar yang komprehensif serta bisa mengakomodasi transaksi-transaksi di lembaga-lembaga keuangan syariah. PSAK 59 tentang Akuntansi Perbankan Syariah telah memberikan identitas terhadap praktek akuntansi syariah. Bahkan sebagian kalangan yang awam terhadap akuntansi syariah menganggap bahwa akuntansi syariah hanya mengatur tentang praktik akuntansi perbankan syariah. Hal ini membuat beberapa tokoh akademisi seperti Iwan Triyuwono dan Sofyan Safri Harahap mencoba meluruskan makna serta semangat akuntansi syariah. Akuntansi Syariah tidak hanya sebatas kajian praktik saja, melainkan terdapat nilai-nilai yang diusung dalam proses penggunaan alat "akuntansi" oleh subyek yang dinamakan "akuntan" atau "auditor".

Pada kenyataannya, wacana Akuntansi Syariah sebagai kajian teoritis maupun kajian secara praktis telah berkembang bersama-sama di Indonesia. Bahkan, seiring dengan perkembangan lembaga keuangan syariah di Indonesia seperti perbankan syariah, lembaga keuangan mikro syariah (Baitul Maal wa Tamwil = BMT), asuransi syariah, reksadana syariah, pegadaian syariah dan lembaga keuangan syariah lainnya, membuat Akuntansi Syariah "kewalahan" untuk mengimbangi kecepatan pertumbuhan lembaga-lembaga tersebut.

Akhir November 2006, Ikatan Akuntan Indonesia mengeluarkan Exposure 
Draft Pernyataan Standar Akuntansi Keuangan (PSAK Syariah). PSAK Syariah sekaligus ingin menjawab permasalahan yang selama ini muncul dengan adanya PSAK 59 yang hanya mengatur Akuntansi Perbankan Syariah saja.

Berangkat dari latar belakang tersebut, tulisan ini bertujuan untuk membahas dan mengevaluasi Exposure Draft (ED) PSAK Syariah tersebut. Tulisan ini akan diawali dengan kajian Akuntansi Syariah secara teoritis dan praktis. Bagian kedua akan membahas tentang Sejarah pengaturan standar akuntansi keuangan syariah di Indonesia. Bagian ketiga akan membahas dan mengevaluasi Exposure Draft Kerangka Dasar Penyusunan dan Penyajian Laporan Keuangan Syariah (KDPPLKS). Bagian keempat akan membahas dan mengevaluasi EXposure Draft Penyajian Laporan Keuangan Syariah (ED PSAK 101). Bagian kelima akan membahas dan mengevaluasi ED PSAK 102 sampai dengan ED PSAK 106 secara umum. Bagian terakhir tulisan ini akan ditutup dengan kesimpulan dan saran.

\section{B. KAJIAN AKUNTANSI SYARIAH TEORITIS DAN PRAKTIS}

Kajian tentang Akuntansi Syariah secara teoritis belum lama berkembang di Indonesia. Kajian Akuntansi Syariah semakin menguat seiring dengan perkembangan lembaga-lembaga keuangan syariah yang semakin menjamur di masyarakat. Kajian tentang Akuntansi Islam di Indonesia dimúlai oleh kalangan akademisi seperti Sofyan Safri Harahap yang mulai mewacanakan nilai-nilai Islam dalam Akuntansi Kapitalis pada tahun 1991 dan 1992, iwan Triyuwono yang menyusun disertasi dan kemudian diramu dalam sebuah buku tentang Organisasi danAkuntansi Syariah (1997), dan MAkhyarAdnan yang juga menyusun disertasi tentang praktik akuntansi pada sebuah bank syariah di Malaysia.

Triyuwono (2006: 27-30), menyatakan bahwa wacana akuntansi syariah telah berkembang di Indonesia ṡejak tahun 1997 serta secara alamiah wacana akuntansi membelah menjadi dua bagian yaitu akuntansi syariah filosofis-teoritis dan akuntansi syariah praktis. Padā tingkatan filosofis-teoritis ini wacana difokuskan pada metodologi bagaimana kita bisa membangun dan mengembangkan akuntansi syariah. Secara umum, wacana pada aspek ini menggunakan pendekatan deduktif-normatif. Pendekatan ini bermula pada konsep yang umum dan abstrak, kemudian diturunkan pada tingkat yang lebih konkret dan prag-matis. Wacana ini mulai dari penetapan tujuan akuntansi, kemudian ke teori, dan akhirnya ke teknik akuntansi.

Tujuan akuntansi disajikan sangat bervariasi. Triyuwono (1995; 1996a; 1997; 2000a), misalnya, dengan menggunakan teologi pembebasan tauhidnya menetapkan tujuan Akuntansi Syariah sebagai instrumen untuk membebaskan manusia dari ikatan jaringan kuasa kapitalisme atau jaringan kuasa lainnya yang semu, dan kemudian diikatkan pada jaringan kuasa llahi. Dengan informasi yang dihasilkan oleh Akuntansi Syariah ini akan tercipta realitas tauhid, yaitu realitas yang sarat dengan jaring kuasa tauhid yang mendorong manusia pada kesadaran tauhid.

Sedangkan menurut Harahap (1997:120) tujuan dari Akuntansi Syariah adalah mengungkapkan kebenaran, kepastian, keterbukaan, keadilan, dan akuntabilitas dari transaksi-transaksi yang dilakukan oleh perusahaan, Jika 
Rifqi Muhammad : Studi Kritis Exposure Draft PSAK Syariah

dibandingkan dengan Triyuwono (1995; 1996a; 1997; 2000a), pendapal Harahap ini tampak lebih konkret, meskipun masih memerlukan proses penerjemahan pada tingkat praktik. Sementara Gambling dan Karim (1991) berorientasi pada tujuan pengungkapan zakat yang harus dibayarkan oleh perusahaan. Orientasi ini membawa konsekuensi pada perombakan bentuk akuntansi.

Senada dengan yang diungkapkan oleh Gambling dan Karim (1991), Triyuwono (1995; 1996a; 1997; 2000a) juga menganggap penting orientasi zakat sebagai tujuan yang lebih konkret dari Akuntansi Syariah. Bahkan Triyuwono (1995; 1996a; 1997; 2000a) secara tegas mengatakan bahwa budaya perusahaan (corporate culture) dapat diciptakan dengan menggunakan metafora zakat (zakat metaphorised organisational reality). Perusahaan dengan menggunakan metafora zakat ini, menurut Triyuwono (1995; 1996a; 1997; 2000a), merupakan instrumen untuk menciptakan realitas tauhid. Disini, Triyuwono (1995; 1996a; 1997; 2000a) berargumentasi bahwa ketika budaya perusahaan telah diciptakan dengan dasar etika syariah, maka akuntansi yang digunakan oleh perusahaan untuk merefleksikan realitas perusahaan harus dibangun dengan nilai etika yang sama. ini jelas menunjukkan letal relevansi diperlukannya Akuntansi Syariah.

Penentuan tujuan Akuntansi Syariah sangat penting bagi pendekatan ini, karena dari tujuan ini kemudian diturunkan konsep-konsep yang lebih konkret dan praktis. Pada tingkat teori, Baydoun dan Willett (1994) telat memberikan kontribusi yang sangat bagus. Mereka memberikan pemikiran pada aspek bentuk laporan keuangan dengan menggunakan pendekatan nilai-tambah (added-value approach). Meskipun pemikiran mereka berada dalam perspektif islam, bentuk laporan keuangan yang mereka usulkan berbeda dengan yang diungkapkan oleh Triyuwono (1995; 1996a; 1997;2000a) dan Gamling dan Karim (1991). Artinya, Baydoun dan Willett (1994) tidak berorientasi pada zakat, tetapi berorientasi pada pendistribusian nilai tambah (value-added distribution) yang lebih merata kepada pihak-pihak yang berkepentingan (stakeholders').

Di sisi lain, akuntansi syariah praktis adalah akuntansi (syariah) yang sudah dipraktikkan dalam dunia nyata. Di Indonesia dan dunia internasional, Akuntansi Syariah hanya dipraktikkan di lembaga keuangan syariah, yaitu: bank syariah. Di Indonesia, barangkali hanya karya Widodo dkk. (1999) yang bisa kita anggap sebagai karya konkret dan praktis tentangAkuntansi Syariah. Widodo dkk. (1999) secara khusus menulis dan merumuskan konsep-konsep teknis akuntansi untuk Baitul Maal wa Tamwil (BMT). Karya ini sangat bagus, karena penyajiannya sangat konkret dan langsung bisa dipraktikkan. Karya ini adalah karya yang hanya satu-satunya memberikan pedoman untuk praktik akuntansi yang dilakukan oleh BMT.

\section{SEJARAH PENGATURAN AKUNTANSI KEUANGAN SYARIAH INDONESIA}

Sejak pertama kali didirikan sekitar tahun 1940-an di Pakistan dan Mesir, Bank Islam atau di Indonesia biasa disebut juga dengan bank syariah menunjukkan perkembangan yang pesat. Menurut Tim Pengembangan Perbankan Syariah Institut Bankir Indonesia (2001: 23) misi-misi bank syariah dibeberapa negara antara lain:

1. Sesuai syariah, transaksi komersial yang menguntungkan, tumbuh 
dan berkembang (Bank Islam Malaysia Berhad)

2. Menciptakan kesejahteraan, kesetaraan dan keadilan pad semua aktivitas ekonomi (Islamic Bank Bangladesh Limited).

3. Sesuai syariah, jasa perbankan dan investasi (Kuwait Finance House).

4. Mempromosikan, memelihara, dan mengembangkan prinsip-prinsip syariah, menggalakkan investasi dan entrepreneurship yang halal (Faysal Islamic of Bahrain).

5. Sesuai syariah, penyediaanjasa perbankan, pembiayaan, dan investasi (Jordan Islamic Bank).

6. Sesuai syariah, profitable, social concern (Bank Muamalat Indonesia).

Antonio (2001: 225) menjelaskan bahwa karena adanya sejumlah perbedaan dalam pelaksanaan operasional antara bank syariah dan bank konvensional, ketentuan - ketentuan perbankan perlu disesuaikan agar memenuhi ketentuan syariah sehingga bank syariah dapat beroperasi secara efaktif dan efisien. Ketentuan - ketentuan tersebut antara lain adalah hal-hal yang mengatur:

1. Instrumen yang diperlukan untuk mengatasi masalah likuiditas,

2. Instrumen moneter yangsesuai dengan prinsip syariah untuk keperluan pelaksanaan tugas bànk sentral,

3. Standar akuntansi, audit, dan pelaporan

4. Ketentuan-ketentuan yang mengatur mengenai prinsip kehati-hatian, dan sebagainya.

Jadijelaslah bahwa salah satu aspekpenting dalam pengaturan operasional bank syariah adalah akuntansi yang merupakan media pertanggungjawaban dan penyampaian informasitentang kinerja daribank syariah. Dengan dasar pemikiran ini, maka masyarakat akuntansi Islam internasional akhirnya membentuk Accounting and Auditing Organization for Islamic financial Institutions (AAOIFI) sebelumnya bernama Financial Accounting Organization for Islamic Banks and Financial Institution (FAO-IFI)didirikan pada tanggal 1 Safar $1410 \mathrm{H}$ atau 26 Februari 1990 di Aljiria. Yang kemudian disahkan sebagai organisasi non-profit yang independen di Bahrain pada 11 Ramadhan 1411H atau 27 maret 1991 (AAOIFl, 1998). Di Indonesia sendiri akhirnya pada 1 Mei 2002 telah disahkan PSAK 59 Akuntansi Perbankan Syariah dan Kerangka Dasar Penyusunan Laporan Keuangan Bank Syariah yang resmi berlaku sejak 1 Januari 2003. Adapun kronologis penyusunan PSAK perbankan syariah dijelaskan oleh Yanto (2003) sebagai berikut:

1. Januari - Juni 1999, masyarakat mulai memberi usulan mengenai standar akuntansi untuk bank syariah.

2. Juli 1999, usulan masuk agenda dewan konsultatif SAK.

3. Agustus 1999, dibentuk tim penyusun pernyataan SAK bank syariah.

4. Desember 2000, Tim penyusun menyelesaikan konsep exposure draft

5. 1 Juni 2001, exposure draft disahkan mengenai Kerangka Dasar Penyusunan dan Penyajian Laporan Keuangan Bank Syaria'ah dan PSAK Akuntansi Perbankan Syariah.

6. 1 Mei 2002, pengesahan Kerangka Dasar Penyusunan dan Penyajian Laporan Keuangan Bank Syaria'ah dan PSAK Akuntansi Perbankan Syariah. 
Rifqi Muhammad : Studi Kritis Exposure Draft PSAK Syariah

7. 1 Januari 2003, mulai berlaku Kerangka Dasar Penyusunan dan Penyajian Laporan Keuangan Bank Syariah dan PSAK Akuntansi Perbankan Syariah.

Setelah 3 tahun digunakan, banyak kalangan yang merasa bahwa PSAK 59 hanya bisa diaplikasikan pada tiga jenis entitas saja seperti yang tertuang dalam ruang lingkup Akuntansi Perbankan Syariah yaitu bahwa PSAK 59 hanya digunakan untuk Bank Umum Syariah (BUS), Unit Usaha Syariah (UUS), dan Bank Perkreditan Rakyat Syariah (BPRS).

Akhirnya, pada tanggal 18 Oktober $2005 \mathrm{IAl}$ merespon dengan membentuk Komite Akuntansi Syariah (KAS) yang bertugas untuk merumuskan Standar Akuntansi Keuangan Syariah. Dalam waktu 1 tahun setelah berdirinya KAS berupaya memberikan sumbangan dengan membangun konsep Prinsip Akuntansi Syariah yang Berlaku Umum (house of Generally Accepted Syariah Accounting Principles), Kerangka Dasar Penyusunan dan Penyajian Laporan Keuangan Syariah, serta enam konsep ED PSAK Syariah.

19 September 2006 Dewan Standar Akuntansi Keuangan (DSAK) menyetujui untuk menyebarluaskan Exposure Draft PSAK Syariah yang terdiri dari:

1. Kerangka Dasar Penyusunan dan Penyajian Laporan Keuangan Syariah (KDPPLKS)

2. PSAK 101 :Penyajian Laporan Keuangan Syariah

3. PSAK 102 : Akuntansi Murabahah

4. PSAK 103 : Akuntansi Salam

5. PSAK 104 : Akuntansi Istishna

6. PSAK'105 : AkuntansiMudharabah

7. PSAK 106 : Akuntansi Musyarakah

Dewan Standar Akuntansi Keuangan (DSAK) bahkan telah menyetujui tentang kelompok nomor (block number) untuk PSAK Syariah yaitu nomor 101 sampaidengan nomor 200. Hal ini menunjukkan keseriusan IAI dalam merespon perkembangan praktik Akuntansi di lembaga-lembaga keuangan syaiah di Indonesia.

D. ED KERANGKA DASAR PENYUSUNAN DAN PENYAJIAN LAPORAN KEUANGAN SYARIAH (KDPPLKS)

Secara garis besar, KDPPLKS merupakan penyempurnaan dari ketentuan yang diatur dalam KDPPLK Bank Syariah. Semangat yang dibangun dari KDPPLKS ini adalah berupaya melakukan generalisasi transaksi-transaksi syariah yang dilakukan entitas-entitas syariah maupun konvensional seperti yang termuat unsur-unsur laporan keuangan pada paragraf 8 :

Kerangka dasar ini berlaku untuk semua jenis transaksi syariah yang dilaporkan dalam laporan keuangan entitas syariah maupun entitas konvensional, baik sektor publik maupun sektor swasta. Entitas syariah pelapor adalah entitas syariah yang laporan keuangannya digunakan oleh pemakai yang mengandalkan laporan keuangan tersebut sebagai sumber utama informasi keuangan entitas 
syariah.

Generalisasi dilakukan dengan jalan mengeliminasi istilah bank syariah yang selama ini melekat di dalam KDPPLK Bank Syariah dan PSAK 59 menjadi entitas syariah. Dari paragraf 8 ini tampak bahwa penyusun KDPPLKS menginginkan semua transaksi syariah yang dilakukan oleh entitas yang bersifat komersial maupun non komersial baik yang berbasis syariah maupun tidak bisa menggunakan kerangka ini sebagai acuan pencatatan transaksi-transaksi syariahnya.

Namun demikian, KDPPLKS ini belum bisa melepaskan diri dari KDPPLK Bank Syariah yang telah disusun sebelumnya. KDPPLKS ini masih cenderung lebih sesuai memang diterapkan di industri perbankan syariah. Hal ini diperkuat dengan pernyataan yang termuat di dalam paragraph 7 :

Laporan keuangan merupakan bagian dariproses pelaporan keuangan. Laporan keuangan yang lengkap meliputi laporan keuangan atas kegiatan komersial dan atau sosial. Laporan keuangan kegiatan komersial meliputi neraca, laporan laba rugi, laporan perubahan posisi keuangan (yang dapat disajikan dalam berbagai cara seperti, misalnya, sebagai laporan arus kas, atau laporan perubahan ekuitas); laporan perubahan dana investasi terikat, catatan dan laporan lain serta materi penjelasan yang merupakan bagian integral darilaporan keuangan. Laporan keuangan atas kegiatan sosial meliputilaporan sumber dan penggunaan dana zakat, dan laporan sumber dan penggunaan dana kebajikan. Di samping itu juga termasuk, skedul dan informasi tambahan yang berkaitan dengan laporan tersebut, misalnya, informasi keuangap segmen industri dan geografis.

Paragraf 7 ini mencerminkan implementasi fungsi dari bank syariah yang menganut ruh Baitul Maal wa Tamwil (BMT), dimana baitul maal merupakan implementasi fungsi sosial dari perbankan syariah sedangkan baitut tamwil merupakan implementasi fungsi komersial dari bank syariah. Hal ini lebih diperkuat lagi dengan penyataan pada paragraf 68:

Sesuai karakteristik maka laporan keuangan entitas syariah antara lain meliputi:

(a) komponen laporan keuangan yang mencerminkan kegiatan komersial:

(i) laporan posisi keuangan;

(ii) laporan labarugi;

(iii) laporan aruskas; dan

(iv) laporan perubahan ekuitas.

(b) komponen laporan keuangan yang mencerminkan kegiatan sosial:

(i). laporan sumber dan penggunaan dana zakat; dán

(ii) laporan sumber dan penggunaan dana kebajikan.

(iii) komponen laporan keuangan lainnya yang mencerminkan kegiatan dan tanggung jawab khusus entitas syariah tersebut.

Kalau memang penyusun KDPPLKS memiliki semangat untuk melakukan generalisasi secara menyeluruh maka seharusnya perlu adanya penjelasan 
tentang lembaga-lembaga keuangan syariah apa saja yang sesuai dengan konsep KDPPLKS ini. Penulis berpendapat bahwa KDPPLKS ini lebih sesuai untuk entitas syariah yang bersifat komersial lebih khusus lagi perbankan syariah. Penulis belum melakukan penelusuran tentang model laporan keuangan entitas syariah lain yang bersifat komersial seperti asuransi syariah, reksadana syariah, pegadaian syariah dll.

Melihat komponen laporan keuangan entitas syariah yang disajikan rasanya kurang sesuai dengan kondisi entitas syariah yang bersifat non komersial seperti Badan Amil Zakat, Lembaga Amil Zakat, dan Badan Wakaf. Baru-baru ini misalnya, Forum Zakat (FOZ) sebagai forum koordinasi antara BAZ dan LAZ di seluruh Indonesia juga mengeluarkan Pedoman Akuntansi Organisasi Pengelola Zakat (PA-OPZ) Tahun 2005. OPZ jelas merupakan organisasi nirlaba yang sampai saat ini juga belum memiliki standar akuntansi keuangan. Jika ingin merujuk pada KDPPLKS ini, ada beberapa hal yang kurang sesuai antara lain:

1. Komponen laporan keuangan yang mencerminkan kegiatan komersial antara lain: laporan posisi keuangan, laporan rugi laba, laporan perubahan ekuitas, maupun laporan arus kas. Padahal OPZ jelas tidak memiliki kegiatan komersial sehingga pernyataan bahwa laporan posisi keuangan merupakan cerminan dari kegiatan komersial tentunya tidak bisa diterapkan dalam OPZ.

2. Menurut PA-OPZ Tahun 2005, unsur-unsur laporan keuangan OPZ terdiri dari: neraca, laporan sumber dan penggunaan dana, laporan arus kas, dan catatan atas laporan keuangan. Dari unsur-unsur laporan keuangan ini, hanya laporan sumber dan penggunaan dana zakat saja yang bisa diakomodasi oleh organisasi nirlaba seperti OPZ ini.

3. Asumsi dasar yang dipakai di dalam KDPPLKS adalah Dasar Akrual seperti yang termuat pada paragraf 41 dan paragraf 42.

41. Untuk mencapai tujuannya, laporan keuangan disusun atas dasar akrual. Dengan dasar ini, pengaruh transaksidan peristiwa lain diakui pada saat kejadian (dan bukan pada saat kas atau setara kas diterima atau dibayar) dan diungkapkan dalam catatan akuntansi serta dilaporkan dalam laporan keuangan pada periode yang bersangkutan. Laporan keuangan yang disusun atas dasar akrual memberikan informasi kepada pemakai tidak hanya transaksi masa lalu yang melibatkan penerimaan dan pembayaran kas tetapi juga kewajiban pembayaran kas di masa depan serta sumber daya yang merepresentasikan kas yang akan diterima di masa depan. Oleh karena itu, laporan keuangan menyediakan jenis informasi transaksi masa lalu dan peristiwa lainnya yang paling berguna bagi pemakai dalam pengambilan keputusan ekonomi.

42. Penghitungan pendapatan untuk tujuan pembagian hasil usaha menggunakan dasar kas. Dalam hal prinsip pembagian hasil usaha berdasarkan bagi hasil, pendapatan atau hasil yang dimaksud adalah keuntungan bruto (gross profit).

Dasar Akrual pada praktik akuntansi OPZ masih bisa diterima karena dalam kenyataannya (accrual basis) telah menjadi asumsi dasar yang diterima 
secara internasional. Namun demikian, bagi OPZ asumsi pada paragraf 42 tentunya tidak sesuai diterapkan karena paragraf 42 tersebut jelas merupakan konsep yang diterapkan dalam praktik perbankan syariah. Bagi OPZ, dasar kas digunakan pada saat OPZ akan memberikan hak amil sebagaibagian dari bentuk hak yang diterima amil dengan asumsi bahwa amil tersebut memang berkerja di OPZ sebagai mata pencahariannya sehingga apa yang diberikan kepada amil merupakan hak OPZ yang memang benar-benar sudah diterima.

\section{ED PSAK 101 \\ Penyajian Laporan Keuangan Syariah}

ED PSAK 101 tentang Penyajian Laporan Keuangan Syariah ini memiliki motivasi untuk mengatur tujuan umum laporan keuangan untuk entitas syariah seperti yang termuat pada paragraf 1.

Pernyataan ini bertujuan untuk mengatur penyajian dan pengungkapan laporan keuangan untuk tujuan umum (general purpose financial statements) untuk entitas syariah yang selanjutnya disebut "laporan keuangan", agar dapat dibandingkan baik dengan laporan keuangan entitas syariah periode sebelumnya maupun dengan laporan keuangan entitas syariah lain. Pengakuan, pengukuran, penyajian, dan pengungkapan transaksi dan peristiwa tertentu diatur dalam Pernyataan Standar Akuntansi Keuangan (PSAK) terkait.

Berkaitan dengan paragraf 1, ruang lingkup penerapan PSAK Syariah ini juga termuat pada paragraf 2 dan 3 yang menyatakan:

2. Pernyataan ini diterapkan dalam penyajian laporan keuangan entitas syariah untuk tujuan umum yang disusun dan disajikan sesuai dengan Pernyataan Standar Akuntansi Keuangan.

3. Entitas syariah yang dimaksud di PSAK ini adalah entitas yang melaksanakan kegiatan usaha berdasarkan prinsip-prinsip syariah yang dinyatakan dalam anggaran dasarnya.

Berbeda dengan PSAK 59 yang secara konkret menjelaskan ruang lingkup penerapan PSAK 59 secara tegas yaitu diterapkan pada Bank Umum Syariah, Unit Usaha Syariah, dan Bank Perkreditan Rakyat Syariah. Kedua paragraf di atas telah berhasil melakukan generalisasi laporan keuangan syariah yang diterapkan pada entitas yang melaksanakan kegiatan usaha menurut prinsip syariah sesuai dengan yang dinyatakan dalam anggaran dasarnya. Sehingga memang tidak semua entitas baik syariah maupun konvensional perlu menyatakan dengan jelas dalam anggaran dasarnya tentang transaksi-transaksi apa yang dilakukan dengan dasar akad-akad syariah sehingga perlakuan akuntansi dan penyusunan laporan keuangan perlu disesuaikan dengan PSAK Syariah ini.

Mencermati lebih lanjut, PSAK 101 ini memuat adanya solusi bagi entitas nirlaba, seperti telah diutarakan pada bagian KDPPLKS, memang PSAK 101 lebih sesuai bagi entitas syariah komersial. Hal ini ditegaskan pada paragraf 6: 
6. Pemyataan ini menggunakan terminologi yang cocok bagi entitas syariah yang berorientasi profit, termasuk entitas bisnis sektor publik. Entitas nirlaba syariah, entitas sektor publik, pemerintah dan entitas syariah lainnya yang akan menerapkan standar ini mungkin perlu melakukan penyesuaianpenyesuaian terhadap deskripsi beberapa pos yang terdapat dalam laporan keuangan dan istilah laporan keuangan itu sendiri serta dapatpula menyajikan komponen-komponen tambahan dalam laporan keuangannya.

Seharusnya, PSAK syariah ini juga mengatur secara konkret ruang lingkup berlakunya PSAK Syariah ini agar pemakai laporan keuangan serta entitas syariah yang dimaksud tidak mengalami kebingungan. PSAK Syariah ini seolaholah sangat umum sekali penerapannya sehingga dikhawatirkan entitas syariah kesulitan menerepkan ketentuan PSAK Syariah ini.

\section{Investasi Terikat dalam PSAK 59}

Dalam PSAK 59 terdapat laporan perubahan investasi terikat dengan definisi investasi terikat merupakan investasi yang bersumber dari pemilik dana investasi terikat dan sejenisnya yang dikelola oleh bank sebagai manajer investasi berdasarkan mudharabah muqayyadah atau sebagai agen investasi. Investasi terikat bukan merupakan aktiva maupun kewajiban bank karena bank tidak mempunyai hak untuk menggunakan atau mengeluarkan investasi tersebut serta bank tidak memiliki kewajiban mengembalikan atau menanggung risiko investasi. 169. Keuntungan atau kerugian investasi terikat sebelum dikurangi bagian keuntungan manajer investasi adalah jumlah kenaikan atau penurunan bersih nilai investasi terikat selain kenaikan yang berasal dari penyetoran atau penurunan yang berasal dari penarikan.

170. Dalam hal bank bertindak sebagai manajer investasi dengan akad mudharabah muqayyadah, bank mendapatkan keuntungan sebesar nisbah atas keuntungan investasi. Jika teriadi kerugian, maka banktidak memperoleh imbalan apapun. Apabila dalam investasi tersebut terdapat dana bank maka bank menanggung kerugian sebesar bagian dana yang diikutsertakan.

171. Dalam hal bank bertindak sebagai agen investasi, imbalan yang diterima adalah sebesar jumlah yang disepakati tanpa memperhatikan hasil investasi.

PSAK 59 meminta bank syariah untuk menyusun laporan perubahan dana untuk investasi terikat guna mengakomodasi keinginan shahibul maal agar dana investasinya disalurkan sesuai keinginannya. Hal ini tentunya membawa konsekuensi seperti yang tercantum dalam paragraf $169 \mathrm{~s} / \mathrm{d} 171$. Intinya, bank syariah hanya sebagai agen perantara dan risiko investasi menjadi tanggung jawab shahibul maa/sepanjang tidak terbukti adanya wanprestasi dari mudharib.

Dana Syirkah Temporer

Pada KDPPLKS sudah tidak nampak lagi adanya pemisahan antara 
investasi terikat dan investasi yang tidak terikat. KDPPLKS menempatkan invetasi terikat (mudharabah muqayyadah) dijadikan satu dalam rekening dana syirkah temporer seperti yang tercantum pada paragraf 87 berikut:

87. Dana syirkah temporer adalah dana yang diterima oleh entitas syariah dimana entitas syariah mempunyai hak untuk mengelola dan menginvestasikan dana, baik sesuai dengan kebijkan entitas syariah atau kebijakan pembatasan dari pemilik dana, dengan keuntungan dibagikan sesuaidengan kesepakatan; sedangkan dalam hal dana syirkah temporer berkurang disebabkan kerugian normal yang bukan akibat dari unsur kesalahan yang disengaja, kelalaian, atau pelanggaran kesepakatan, entitas syariah tidak berkewajiban mengembalikan atau menutup kerugian atau kekurangan dana tersebut. Contoh dari dana syirkah temporer adalah penerimaan dana dari investasi mudharabah mutlaqah, mudharabah muqayyadah, musyarakah, dan akun lain yang sejenis.

88. Dana syirkah temporer tidak dapat digolongkan sebagai kewajiban. Hal ini karena entitas syariah tidak berkewajiban, ketika mengalami kerugian, untuk mengembalikan jumlah dan awal dari pemilik dana kecuali akibat kelalaian atau wanprestasi entitas syariah. Di sisi lain, dana syirkah temporer tidak dapat digolongkan sebagai ekuitas karena mempunyai waktu jatuh tempo dan pemilik dana tidak mempunyai hak kepemilikan yang sama dengan pemegang saham, seperti hak voting dan hak atas realisasi keuntungan yang berasal dari aset lancar dan aset non investasi (current and other non investment accounts)

Perubahan dari investasi terikat menjadi syirkah temporer merupakan perubahan yang cukup signifikan karena di dalam konsep PSAK 59, investasi terikat dalam PSAK 59 tersebut hanya mengakomodasi adanya investasi dengan model mudharabah muqayyadah, namun dengan adanya syirkah temporer, maka investasi mudharabah mutlaqah yang awalnya diakui sebagai investasi tidak terikat sekarang beralih menjadi syirkah temporer dengan asumsi bahwa penghimpunan dana mudharabah lebih menekankan pada investasi sehingga pemilik dana (shahibul maal) memiliki risiko untung atau rugi.

Namun demikian, seharusnya dalam penjelasan syirkah temporer perlu ditambahkan dengan informasi tentang ketentuan perlakulan mudharabah muqayyadah seperti yang ada di dalam PSAK 59 khususnya paragraf 170 berkaitan dengan pola bagi hasil dan pemberian imbalan bagi bank selaku agen sehingga membedakan antara perlakuan mudharabah mutlaqah dan mudharabah muqayyadah karena kedua akad tersebut memiliki konsekuensi yang berbeda. Kalau ditinjau dari sisi efisiensi, perubahan ini membawa dampak yang baik karena entitas syariah seperti bank syariah tidak perlu lagi menyusun laporan perubahan dana investasi terikat.

Syirkah Temporer menggabungkan semua dana (Pooling of Fund) Agak berbeda dengan konsep PSAK 59 khususnya berkaitan dengan 
perlakuan terhadap investasi terikat, dimana pemilik dana diperkenankan meminta bank syariah untuk memisahkan dananya dengan jenis dana yang lain (tidak mencampurkan). Dalam konsep syirkah temporer terdapat ketentuan seperti yang tercantum pada paragraf 89 dan 90 sebagai berikut:

89. Hubungan antara entitas syariah dan pemilik dana syirkah temporer merupakan hubungan kemitraan berdasarkan akad mudharabah muthlaqah, mudharabah muqayyadah atau musyarakah. Entitas syariah mempunyai hak untuk mengelola dan menginvestasikan dana yang diterima dengan atau tanpa batasan seperti mengenai tempat, cara, atau obyek investasi.

90. Dana syirkah temporer merupakan salah satu unsur neraca dimana hal tersebut sesuai dengan prinsip syariah yang memberikan hak kepada entitas syariah untuk mengelola dan menginvestasikan dana, termasuk untuk mencampur dana dimaksud dengan dana lainnya.

Konsep dana syirkah temporer ini dibuat lebih fleksibel pada paragraf 89 namun kalau dihubungkan dengan paragraf 90 nampak kurang konsisten karena entitas syariah memiliki kewenangan yang luas termasuk mencampurkan dana dengan jenis dana yang lain.

Seharusnya, ada penjelasan lebih lanjut tentang perlakuan untuk masingmasing dana syirkah temporer yang dikelola seperti misalnya untuk dana mudharabah muqayyadah tentunya diatur perlakuan khusus mengingat investasi ini merupakan investasi khusus dimana pemilik dana punya kewenangan lebih untuk mengatur tempat, cara, atau obyek investasi.

\section{E. LAPORAN SUMBER DAN PENGGUNAAN DANA ZAKAT}

Pada PSAK 59 masih mencantumkan pengelolaan dana Zakat, Infaq, dan Shodaqoh, namun dalam ED PSAK 101 hanya mengakomodasi pengelolaan dana zakat saja baik yang berasal dari luar entitas syariah maupun dari dalam entitas syariah. Dana infaq dan shodaqoh kemudian dialihkan dalam Laporan Sumber dan Penggunaan Dana Kebajikan. Sebelumnya PSAK 59 mencantumkan Dana Kebajikan ini sebagai Dana Qordhul Hasan. Perubahan ini bisa dipahami sebagai upaya agar istilah Dana Kebajikan lebih bisa diterima.

\section{ED PSAK $102-106$}

Pada prinsipnya akad-akad transaksi syariah yang terdapat pada ED PSAK 102 (Akuntansi Murabahah), ED PSAK 103 (Akuntansi Salam), ED PSAK 104 (Akuntansi Istishna), ED PSAK 105 (Akuntansi Mudharabah), dan ED PSAK 106 (Akuntansi Musyarakah) tidak mengandung perbedaan yang cukup signifikan secara substansi.

Perbedaannya terletak pada ruang lingkup pemberlakuan transaksitransaksi syariah yang dimaksud lebih umum, tidak terbatas praktik di perbankan syariah saja (BUS, UUS, dan BPRS). Hal ini dimaksudkan agar LKS yang telah benyak berkembang bisa mengadopsi ketentuan yang ada dalam PSAK Syariah 
ini dalam proses pencatatan akuntansinya. Disamping itu sebenarnya masih banyak yang belum diatur dalam PSAK Syariah seperti yang telah diatur dalam PSAK 59 seperti.standar untuk transaksi ljarah, Qordh dan Sharf (pertukaran valuta asing). Begitu juga untuk dana zakat yang dikelola oleh lembaga keuangan syariah seharusnya juga perlu diatur mengingat salah satu sehdi perekonomian Islam adalah zakat.

Dengan adanya PSAK Syariah khusus PSAK 101 -106, maka keberadaan transaksi-transaksi syariah yang diatur dalam PSAK 59 seperti Murabahah, Salam, Istishna, Mudaharabah, dan Musyarakah akan digantikan dengan ketentuan yang ada dalam PSAK Syariah. Tentunya prosesnya akan dilakukan secara bertahap mengingat menurut ED PSAK Syariah, rencananya seluruh ketentuan dalam PSAK Syariah akan efektif diberlakukan untuk laporan keuangan tahun 2008. Namun, lembaga keuangan syariah disarankan untuk mulai mengadopsi ketentuan-ketentuan PSAK Syariah mulai tahun 2007. Hal ini cukup beralasan mengingat Exposure Draft standar akuntansi keuangan yang biasanya dikeluarkan oleh Ikatan Akuntan Indonesia tidak akan terjadi perubahan yang cukup signifikan.

\section{F. PENUTUP}

Secara garis besar ED PSAK Syariah ini telah memiliki semangat untuk melakukan generalisasi praktik transaksi syariah yang berkembang di Indonesia, namun demikian perlu kiranya Komite Akuntansi Syariah (KAS) melakukan upaya sosialisasi dan uji publik terhadap ketentuan yang ada di dalam PSAK Syariah ini khususnya bagi entitas-entitas syariah atau konvensional di luar perbankan syariah untuk mengetahui tingkat kesesuaian dengan praktik-praktik yang ada. Diharapkan PSAK Syariah ini tidak sekedar "Ganti Baju", namun lebih dari itu diharapkan PSAK Syariah ini mampu menjadi payung praktik akuntansi syariah di Indonesia. 


\section{DAFTAR PUSTAKA}

AAOIFI. (2001). Accounting,,Auditing, and Governance Standard for /slamic Financial Institutions, Bahrain: AAOIFI.

Antonio, Muhammad Syafi'i. (2001). Bank Syariah Dari Teorike Praktek. Jakarta: Gema Insani Press.

Harahap, Sofyan Safri. (2005). Menuju Perumusan TeoriAkuntansi Islam. Jakarta: Pustaka Quantum.

Harahap, Sofyan \& Wiroso. (2005). Akuntansi Perbankan Syariah. Jakarta: LPFE Universitas Tri Sakti.

Ikatan Akuntan Indonesia. (2002). Kerangka Dasar Penyusunan dan Penyajian Laporan Keuangan Bank Syariah. Jakarta: Ikatan Akuntan Indonesia.

. (2002). Pernyataan Standar Akuntansi Keuangan (PSAK) No. 59 Akuntansi Perbankan Syariah. Jakarta: Ikatan Akuntan Indonesia.

Syariah. Jakarta: Ikatan Akuntan Indonesia.

. (2006). Exposure Draft KDPPLKS dan PSAK

Tim Penyusun PA-OPZ. (2005). Pedoman Akuntansi Organisasi Pengelola Zakat. Jakarta: Forum Zakat.

Tim Pengembangan Perbankan Syariah Institut Bankir Indonesia. (2001). Konsep, Produk dan Implementasi Operasional bank Syariah. Jakarta: Djambatan.

Tim Perumus Pedoman Akuntansi Perbankan Syariah Indonesia. (2003). Draft Pedoman Akuntansi Perbankan Syariah Indonesia (PAPSI). Jakarta: IAI.

Triyuwono, Iwan. (2006). Akuntansi Syariah: Perspektif, Metodologi, dan Teori. Jakarta: Rajawali Press.

Widodo, Hertanto, dkk. (2001). Akuntansidan Manajemen Keuangan untuk Organisasi Pengelola Zakat. Jakarta: Institut Manajemen Zakat (IMZ)

Yanto, Sri. (2003). Standar Akuntansi Perbankan Syariah. Disampaikan dalam Seminar Nasional Akuntansi Syariah, Jogja Hall Hotel Santika, Yogyakarta, 15 Maret 2003. 